\title{
Regional-scale forest ecosystem modeling: database development, model predictions and validation using a Geographic Information System
}

\author{
S. G. McNulty ${ }^{1}$, J. M. Vose ${ }^{1}$, W. T. Swank ${ }^{1}$, J. D. Aber ${ }^{2}$, C. A. Federer ${ }^{3}$ \\ ${ }^{1}$ USDA Forest Service, Coweeta Hydrologic Laboratory, 999 Coweeta Lab Rd, Otto, North Carolina 28763, USA \\ ${ }^{2}$ University of New Hampshire, Durham, Morse Hall, Complex Systems Research Center, Durham, New Hampshire 03824, USA \\ ${ }^{3}$ USDA Forest Service, Louis C. Wyman Forest Service Laboratory, PO Box 640, Mast Rd, Durham, New Hampshire 03824, USA
}

\begin{abstract}
Regional-scale forest ecosystem models can provide insight into how forest hydrology and productivity differ in response to variations in climate and soil conditions. However, the databases necessary to define and validate these models are difficult to compile and utilize. The use of a Geographic Information System (GIS) can greatly simplify problems in database management. As an example of regional-scale ecosystem model database development and model validation, the Arc-Info GIS and the PnET-IIS forest ecosystem model were used to predict and validate annual drainage and net primary productivity (NPP) on a $0.5^{\circ} \times 0.5^{\circ} \mathrm{grid}$ (approximately $50 \times 75 \mathrm{~km}$ ) for southern pine forests in the state of Georgia, USA. PnET-IIS is a lump-sum physiological model which used historic climate data from 1951 to 1984 , along with soil water-holding capacity and species-specific vegetation characteristics. Annual predictions of drainage were well correlated with measured United States Geological Survey (USGS) drainage $(r=0.87, p<0.0001)$, and predicted NPP was related with Forest Inventory Assessment (FIA) growth data collected across the state $(r=0.84, p<0.0001)$. This study demonstrated the utility of a GIS in broad-scale ecosystem modeling and suggests that the need for model/GIS interfacing in future research will continue to increase.
\end{abstract}

KEY WORDS: Ecosystem model - PnET - Geographic Information System (GIS) - Net primary productivity (NPP) - Drainage - FIA forest growth - USGS stream flow

\section{INTRODUCTION}

Changes in the amount and distribution of precipitation, and increases in global surface temperature, may occur over large geographic areas during the next century (Mintzer 1990). These climatic changes could have profound impacts on ecosystem processes as decreased precipitation and increased air temperatures could decrease available soil water and increase plant water stress. In turn, these factors would decrease photosynthetic rates, tree growth and soil water use (Long 1991, Esser 1992). Due to the potential social and economic implications of these changes, much effort is being placed on developing broad-scale ecosystem process models to predict the potential impact of climate change on forest hydrology and productivity.
The large temporal and spatial dimensions of this research require that innovative methodologies be employed to construct the databases and to execute and validate the models. A Geographic Information System (GIS) is a powerful tool which can be utilized for all phases of regional-scale ecosystem modeling (Verbyla 1990, Everham et al. 1991). A GIS has existed since the early 1960s (Tomlinson et al. 1976), but only since the mid-1980s have reductions in software and hardware costs and increased program flexibility made such systems viable for ecosystem research (Iverson \& Risser 1987, Johnston 1987, Johnson 1990, Osborne 1990, Davis et al. 1991, Drayton et al. 1992). For these reasons, Lanfear (1989) concluded that the impact of GIS in understanding environmental issues may be as great as that of the introduction of the FORTRAN programming language. This paper discusses 
database development for defining and validating annual southern pine drainage and net primary productivity (NPP) across the state of Georgia, USA, using PC Arc-Info as the GIS and PnET-IIS as the ecosystem model. A well-validated, physiologically based, regional-scale model could be very useful for the study of climate change scenario effects on forest hydrology and productivity.

\section{PnET-IIS model}

PnET-IIS is a derivation of the PnET-II model which was developed by Aber \& Federer (1992) for predicting forest hydrology and productivity in the northeastern United States. In PnET-IIS, some model algorithms related to vegetative respiration and photosynthesis from PnET-II have been replaced with equations which were derived especially for southern pine species (S. G. McNulty, J. M. Vose \& W. T. Swank unpubl.) PnET-IIS was run with monthly climate data and soils information to predict loblolly and slash pine forest hydrology and productivity at a $0.5^{\circ} \times 0.5^{\circ}$ grid cell resolution (approximately $50 \times 75 \mathrm{~km}$ at this longitude and latitude) across Georgia. A $0.5^{\circ} \times 0.5^{\circ} \mathrm{grid}$ cell resolution was selected for model development because future research using PnET-IIS will use general circulation model (GCM) climate data. GCM models are developed at coarse resolutions $\left(\geq 4^{\circ} \times 4^{\circ}\right.$ grid cells), so model outputs below $0.5^{\circ} \times 0.5^{\circ}$ would not reflect actual climate differences as predicted from the GCMs.

There are many type of GIS available (e.g. IDRISI, Arc-Info, GRASS) and, depending on how the GIS is used, system requirements for regional ecosystem modeling vary. In this analysis, monthly climate data and soil series information were entered into a commonly used vector-based GIS called PC Arc-Info (ESRI, version 3.4D, Redlands, CA, USA). A model 80486 personal computer with a $680 \mathrm{MB}$ hard drive and $8 \mathrm{MB}$ of RAM was used for data handling and manipulation.

Monthly predictions of loblolly and slash pine growth and hydrology were calculated using the climate data from 1951 to 1984 . Since the database was in gridded format, PnET-IIS was run on each grid for the entire data record before the next grid data were entered. This process was repeated using an executable FORTRAN batch routine, until all grid points had been completed. The total run time for all 34 years on each of the 79 grid cells across Georgia was approximately $15 \mathrm{~min}$. However, running the model for Georgia is a small section of the total 758 grid cells which represent the spatial area of loblolly pine in the southern U.S. The total run time for the entire region is in excess of $2 \mathrm{~h}$. This research represents an extreme use of personal computers for GIS database development and model execution. For models with greater computational requirements, a workstation environment would be more appropriate.

\section{Database development}

As the scale of ecosystem-level modeling increases, the number of assumptions and amount of data aggregation also increases (Rastetter et al. 1992). At a fine spatial and temporal scale, forest modeling can use dozens of hourly input variables for model predictions, while regional-scale models may use only a few parameters, entered at monthly or greater time steps (Wessman 1992). Most hydrologic models input precipitation and some form of temperature (e.g. average, maximum) over a daily, monthly or annual time step (Ffolliott \& Guertin 1988, Federer \& Lash 1978). In addition, some models incorporate other climatic variables such as relative humidity and net solar radiation with vegetation or soil characteristics (Combs et al. 1988, Running \& Coughlan 1988, Aber \& Federer 1992). Annual estimates of southern pine productivity and hydrology using PnET-IIS require input data on climate, soil water-holding capacity (SWHC), and species-specific vegetation attributes. Database development of each of these input parameters will be discussed separately.

\section{Climate data}

PnET-IIS requires 4 monthly climatic parameters: minimum and maximum air temperature, precipitation and solar radiation. The Forest Health Atlas (Marx 1988) provided cooperator and first-order station data from 1951 to 1984, which were originally acquired from the National Climatic Data Center (NCDC). Over 900 cooperator data stations located across the southern U.S. record minimum and maximum daily air temperature and total daily precipitation. Unchecked cooperator station data from NCDC typically had error rates between 5 and $40 \%$ (Marx 1988), so a large proportion of the data was removed in the Forest Health Atlas. In addition to cooperator data, over 70 first-order climate stations collect daily relative humidity and other data across the region. Historically, the firstorder station data have far fewer errors compared to cooperator station data, so few data points need to be excluded (Marx 1988). The 2 databases were interpolated on a $0.5^{\circ} \times 0.5^{\circ}$ grid across the southern U.S. (Marx 1988). The gridded databases of minimum and maximum air temperature, relative humidity and precipitation were compiled into a single database and 
run through a program to calculate average monthly solar radiation (Nikolov \& Zeller 1992) on a $0.5^{\circ} \times 0.5^{\circ}$ grid. Solar radiation values were then combined with precipitation and monthly maximum and minimum air temperature as climate inputs for PnET-IIS.

\section{Soils data}

Soils series data were derived from a GIS-based Soils Atlas compiled by the Soil Conservation Service (Marx 1988). The soil series data were hand digitized into the Soils Atlas from a paper source at a scale of 1:750000. Soil information associated with each series includes SWHC to a depth of $102 \mathrm{~cm}$, and soil humus depth. Across Georgia, SWHC ranged from 0 (rock outcrops) to $17 \mathrm{~cm} \mathrm{H} \mathrm{H}_{2} \mathrm{O}$ for soil depth of $102 \mathrm{~cm}$ (Fig. 1). SWHC was the only soil input needed to run PnET-IIS. In developing a coverage of average SWHC on a $0.5^{\circ} \times$ $0.5^{\circ}$ grid cell, soils unsuitable for growing southern pines were excluded from the data set. If all SWHC were averaged across a grid cell, very low and high SWHC areas could potentially be averaged within the same grid cell to produce a cell with a pseudo-average SWHC which would appear to be suitable for pine growth. To eliminate this source of input error, we utilized Forest Inventory Assessment (FIA) data which consisted of stand volume, growth and species composition information remeasured at over 21000 permanent plots across the southern U.S. A subset of this database which contained plot locations of loblolly and slash pine FIA plots in Georgia was selected. Arc-Info
Fig. 1. Soil water-holding capacity (SWHC) for Georgia, USA, in a GIS database. Map digitized from a 1:750000 paper source, Soil Conservation Service map
Excluded

3.81 to $6.80 \mathrm{~cm}$

6.81 to $9.80 \mathrm{~cm}$

9.81 to $12.80 \mathrm{~cm}$

12.81 to $15.80 \mathrm{~cm}$ 
was employed to overlay FIA plot locations with a soil series map for the state. This information provided the soil series and associated range of SWHC in which the pines were growing. Loblolly pine stands were located on FIA plots with an SWHC ranging from 3.8 to $15.8 \mathrm{~cm} \mathrm{H} \mathrm{H}_{2} \mathrm{O}$ for soil depths of $102 \mathrm{~cm}$. Approximately $5 \%$ of the total land area across the state contained soils with SWHC values which were greater or less than the SWHC values associated with FIA plots containing loblolly and slash pine and were excluded from calculations of average grid cell SWHC. Using the selected range of SWHC on which loblolly or slash pine were found to grow, the $0.5^{\circ} \times 0.5^{\circ}$ grid cell was then placed over the state and a weighted average of all remaining $\mathrm{SWHC}$ polygons within each grid cell was computed (Fig. 2). This GIS output formed the basis for the soils input to the PnET-IIS model.

\section{Vegetation inputs}

No GIS vegetation overlays were needed to parameterize the PnET-IIS model. Instead, PnET-IIS utilized generalized species-dependent vegetation variables (e.g. growing degree days to start and stop leaf and wood production). Leaf area index (LAI) is one of the important model parameters driving hydrology and productivity processes. In PnET-IIS, LAI is calculated as the maximum sustainable leaf area which could be supported on a site, based on climate and soil conditions. LAI is difficult to measure over large spatial areas, so there are advantages to calculating LAI within the model. However, this technique assumes that the ecosystem can obtain a closed canopy and that there are no reductions in LAI due to insect, disease, nutrient or pollutant stresses.
Fig. 2. Modified $0.5^{\circ} \times 0.5^{\circ}$ gridded map of SWHC for Georgia. Using Forest Inventory Assessment (FIA) plot data for loblolly and slash pine as locations for surtable soil habitat, all soils which were too wet or dry to support a pine forest were removed from the database. A GIS was used to calculate a weighted average of SWHC using the surface area of all unmasked SWHC polygons within each grid cell
Excluded

3.81 to $6.80 \mathrm{~cm}$

6.81 to $9.80 \mathrm{~cm}$

9.81 to $12.80 \mathrm{~cm}$

12.81 to $15.80 \mathrm{~cm}$ 


\section{Regional-scale model validation}

\section{Productivity}

Model validation at the regional scale is difficult because needed data are often not collected over large geographic regions. The FIA database is one source of productivity data which exists over a long temporal period for the whole region. Originally authorized by the McSweeney-McNary Act of 1928, the FIA program was established to develop, analyze and maintain forest resource information needed to formulate policies and programs. The program established over 21000 permanent plots across the southern U.S. which are measured every 8 to $10 \mathrm{yr}$. A number of modifications have been made to the survey system since its inception during the early 1930s. However the methods used for measuring each plot have remained unchanged since the 1970s (Kelly 1991). Within each plot, species type, volume and disturbance (e.g. insect, disease, fire) are recorded for all trees greater than $2.5 \mathrm{~cm}$ diameter, at a height $1.4 \mathrm{~m}$ above the forest floor (i.e. diameter at breast height, DBH). Since the exact position of each tree is recorded, tree mortality and regeneration can also be calculated. From 1970 to 1993, plots in all states across the southern U.S. were measured 3 times. By comparing remeasurement volumes with past volumes, plot growth can be assessed.

However, numerous factors complicate the direct use of plot data. Silvicultural practices (e.g. burning, fertilizing, thinning) can all affect plot growth. PnETIIS predictions of ecosystem growth and productivity are based on natural conditions. For this reason, plots that have a noted disturbance (e.g. silvicultural, insect, disease) between remeasurement periods were removed from the validation data set. In addition, PnET-IIS was run using only loblolly and slash pine, so a validation of the model would need to utilize growth data on sites which only contained these 2 species. The following selection criteria were used for creating the southern pine validation database.

(1) The entire plot must be classified as timberland during 2 consecutive measurement periods.

(2) At least $90 \%$ of the initial basal area of trees $>2.5 \mathrm{~cm}$ diameter at $\mathrm{DBH}$ in each plot location must be comprised of loblolly or slash pine.

(3) The plots must show no evidence of planting or seeding between measurements. Plantations are not excluded from the validation data set, but they must have been established before 1970 .

(4) The plots must have no evidence of fire, fertilization, thinning, harvesting, insect or disease between measurements.

Using these criteria, 170 FIA plots were selected throughout Georgia between the fifth and sixth mea- surement periods (1972 to 1982). However, before the FIA data base could be used for model validation, additional data conditions were required. PnET-IIS assumes that the stand has a closed canopy. FIA pine forest stands are classified as seedling, sapling, pole timber and saw $\log (>20 \mathrm{~cm}$ DBH). For model productivity validation, only sites which were most likely to have a closed canopy at the beginning of the measurement period (i.e. saw log size timber) were compared with PnET-IIS predictions of growth. Additionally, to better represent average growth within each $0.5^{\circ} \times 0.5^{\circ}$ grid cell, at least 2 FIA plots were required per cell, so cells with only 1 FIA plot were excluded from the validation data set. These 2 selection criteria reduced the original FIA data set from 170 to 90 to 47 , respectively. From 1972 to 1982 , the latest remeasurement period for which we have climate data, 19 grid cells $\left(0.5^{\circ} \times 0.5^{\circ}\right)$ were located across Georgia which contained FIA plots meeting the selection criteria. Measured basal-area growth was calculated for each FIA plot by subtracting the 1972 basal area from the 1982 basal area and dividing the resulting value by 10 to convert to annual basal-area growth per plot. The difference in basal area (i.e. growth) between the 2 measurement periods was summed for all FIA plots within each grid cell and divided by the number of plots per cell. The resulting product was average annual FIA measured basal-area growth by cell. Average annual measured basal-area growth ranged from 5.5 to $18 \mathrm{~cm}^{2}$ tree $^{-1}$ cell $^{-1}$. To examine the FIA plot growth data at the same temporal scale as model outputs, PnET-IIS predicted NPP was averaged between 1972 and 1982 for each grid cell.

\section{Hydrology}

Researchers have long utilized USGS stream-flow data for hydrologic modeling, but the emphasis was on model calibration (Dawdy et al. 1972, James 1972, Magette et al. 1976). Basin stream-flow data are useful in broad-scale modeling, calibration and validation because measurements integrate ecosystem water input, movement and usage. The USGS has over 6000 stream-gauging stations across the continental U.S. (USGS 1992) which were used in model validation of regional drainage. USGS point runoff is calculated by dividing the average annual stream flow volume at each stream-gauging station by upstream drainagebasin size. Isopleths are then drawn between areas of equal stream outflow. Using this procedure, average annual runoff data for the southern U.S. were calculated from gauge station data from 1951 to 1980 (Moody et al. 1986). The $0.5^{\circ} \times 0.5^{\circ}$ grid cell was placed over the isopleth map and a weighted average of mean cell runoff was calculated based on the area size and value of all isopleths within each cell. 


\section{RESULTS}

Model output from PnET-IIS was in ASCII format. Each row of output data included month, year, gridcell identification number, annual drainage, and NPP. The output data were read into a prestructured dBase IV file, which could then be accessed by Arc-Info. Once the data were entered into dBase, the final use of a GIS in regional-scale modeling involved output display. Visual representation of this output is much easier to interpret than tabular forms, especially when comparing prediction and validation data at broad spatial scales. GIS output of PnET-IIS predictions of annual drainage and NPP on a $0.5^{\circ} \times 0.5^{\circ}$ grid cell across Georgia is illustrated in Figs. 3 \& 4 .

\section{Hydrology}

PnET-IIS predicted average annual drainage was validated with the USGS runoff data. Validation of runoff data is very simplistic at broad spatial scales and should be viewed with caution since measured runoff is a function of factors not incorporated into PnET-IIS, including steepness of topography, urbanization, species composition and rock permeability. Within PnET-IIS, maximum water-storage capacity is determined by SWHC and monthly evapotranspiration is a function of LAI and climate (i.e. air temperature, vapor pressure deficit). Plant water demand is dependent on monthly precipitation and water stored in the soil profile. If precipitation inputs exceed plant water demand, the soil is first recharged to the SWHC and if water is still available, water is output as drainage. Monthly drainage values are summed to provide an estimation of annual water outflow. PnET-IIS predicted the greatest amount of drainage would occur in northeastern Georgia and the least in the southeast (Fig. 3a). These results are in general agreement with USGS Water Resource runoff maps of the area (Fig. 3b), and the correlation between predicted average annual drainage and USGS measured runoff was significant $(r=0.87, p<0.0001, n=79)$.

\section{(a) PNET}

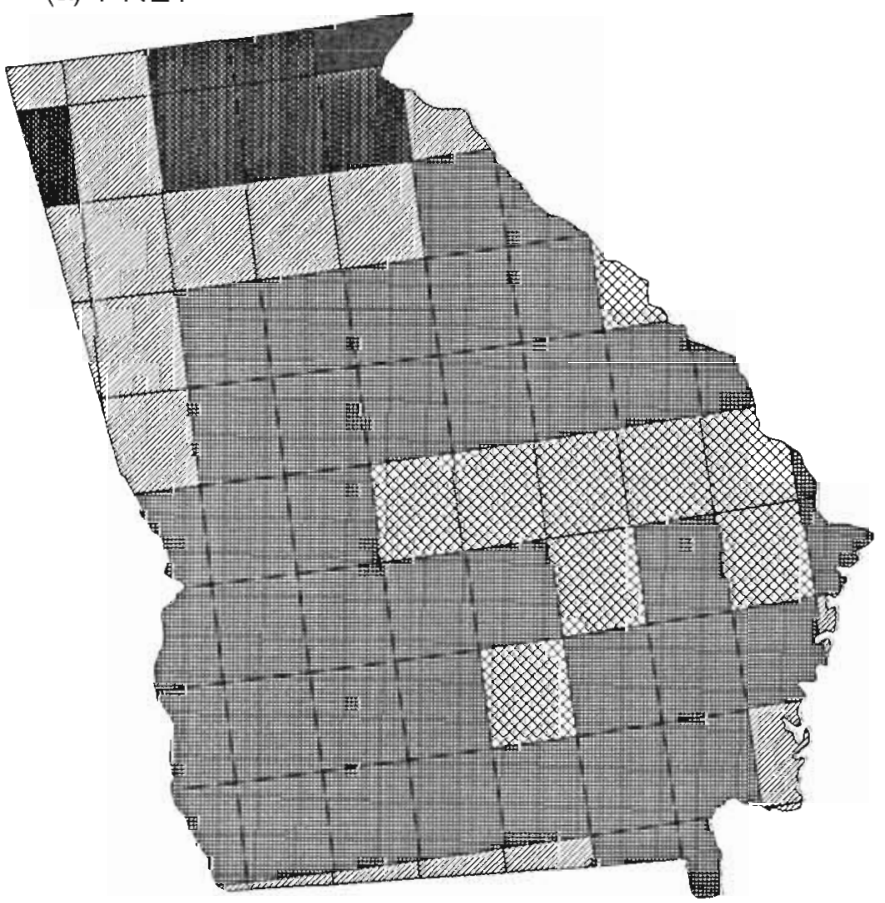

(b) USGS

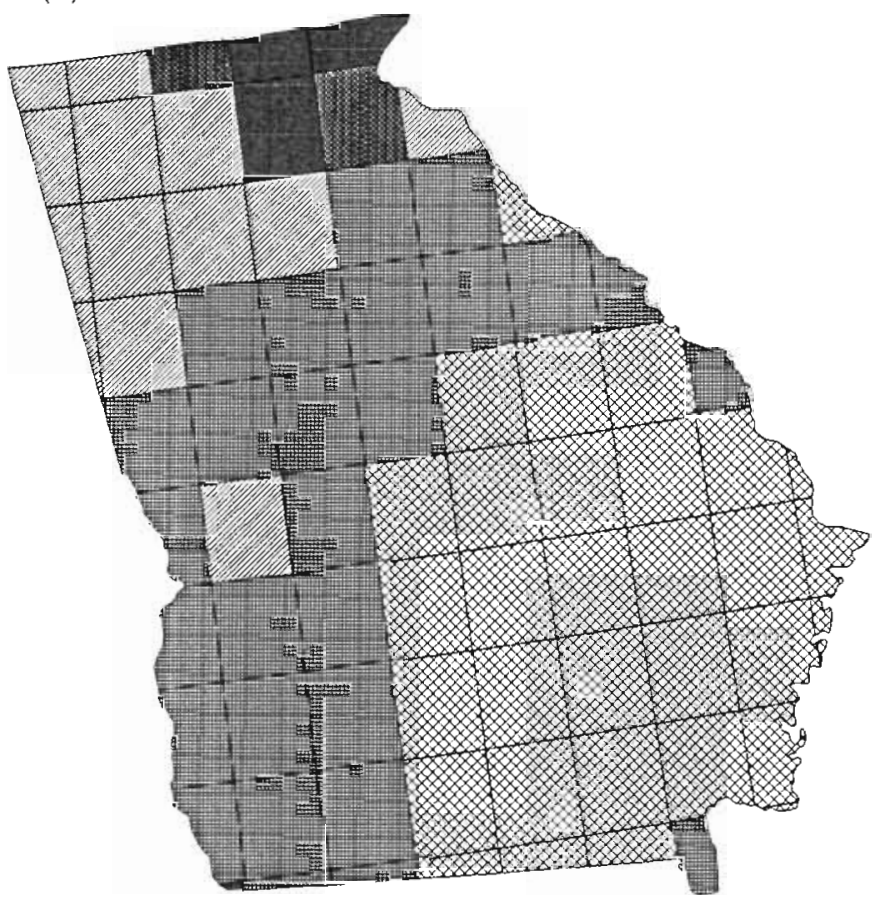

25.1 to $35.0 \mathrm{~cm} \mathrm{yr}^{-1}$ 65.1 to $80.0 \mathrm{~cm} \mathrm{yr}^{-1}$

35.1 to $50.0 \mathrm{~cm} \mathrm{yr}^{-1}$ $>80.0 \mathrm{~cm} \mathrm{yr}^{-1}$
Fig. 3. Comparison between (a) predicted average annual drainage and (b) USGS measured average annual runoff $(\mathrm{cm})$ for 1951 to 1980 on $a .5^{\circ} \times 0.5^{\circ}$ grid across Georgia

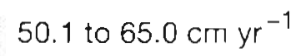




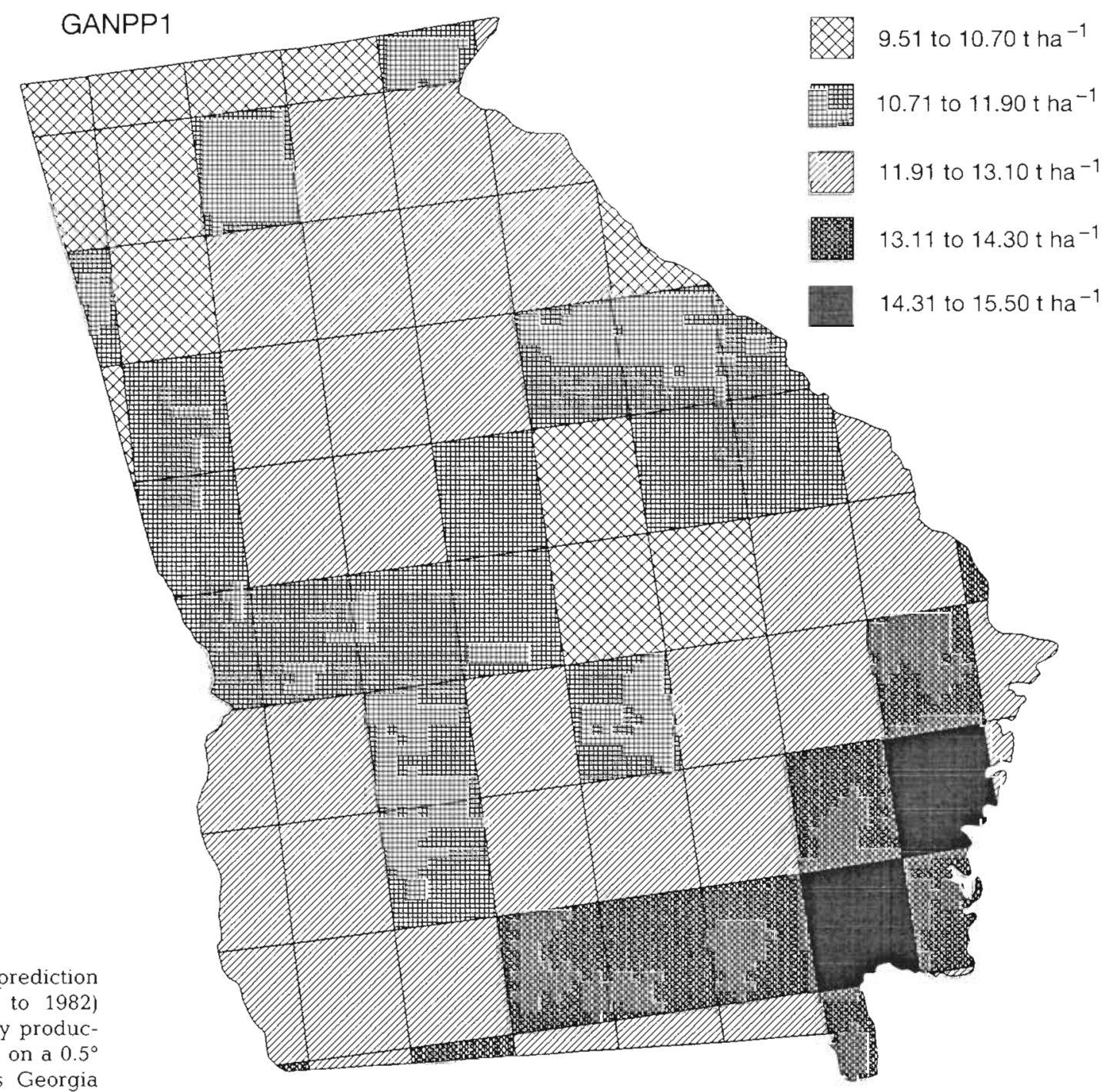

Fig. 4. PnET-IIS prediction of average (1972 to 1982$)$ annual net primary productivity (NPP, $\mathrm{g} \mathrm{m}^{-2}$ ) on a $0.5^{\circ}$ $\times 0.5^{\circ}$ grid across Georgia

\section{Net primary productivity}

Predicted average annual NPP ranged from 9.5 to $15.5 \mathrm{tha}^{-1}$ with the majority of the values between 10.7 and $13.1 \mathrm{t} \mathrm{ha}^{-1}$ (Fig. 4). Teskey et al. (1987) measured a range of above-ground NPP between 2 and $10 \mathrm{tha}^{-1}$ $\mathrm{yr}^{-1}$ on loblolly pine sites. Other studies have estimated that below-ground production is equal to approximately $40 \%$ of above-ground NPP (Nadelhoffer et al. 1985). Multiplying Teskey et al. (1987) measurements of above-ground NPP by 1.4 yields a range of total (above-and below-ground) NPP between 2.8 to 14.0 t biomass ha-1 $\mathrm{yr}^{-1}$.

Across Georgia, average annual measured basalarea growth for trees in FIA plots ranged from 9.8 to $14.4 \mathrm{~cm}$. Measured FIA basal-area growth was significantly correlated with predicted NPP ( $\mathrm{r}=0.84, \mathrm{p}<$
$0.0001 ;$ Fig. 5). These results indicate that with careful screening, FIA data can be successfully utilized for validation of model productivity even though the FIA plots were not originally designed for this purpose, and despite unknowns regarding soil chemistry and past land use in FIA plots.

\section{Future areas of model development}

Once the database had been developed using a GIS and the model had been successfully validated, potential climate change impacts on forest growth and productivity could be evaluated. Atmospheric $\mathrm{CO}_{2}$ con-

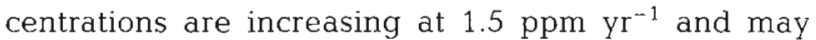
double by the end of the next century (Mooney et al. 1987). Along with increasing atmospheric $\mathrm{CO}_{2}$, aver- 


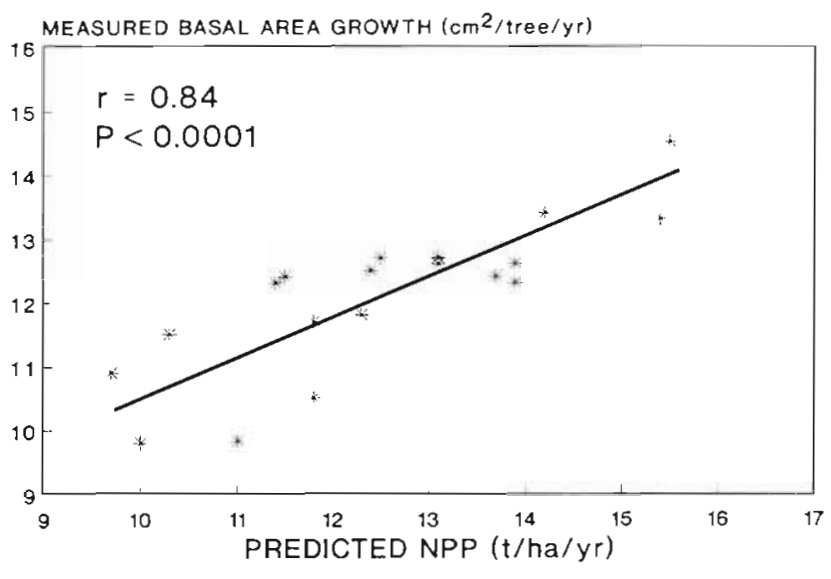

Fig. 5. Correlation between predicted average annual NPP and FIA measured average annual basal-area growth across Georgia from 1972 to 1982

age annual air temperature could increase from 3 to $7^{\circ} \mathrm{C}$ across the southern US (Cooter et al. 1993). PnETIIS in combination with a GIS could be employed to generate, store and display sections of the southern U.S. in which loblolly pine may be particularly affected by climate change. This and other broad-scale questions will assure the continued and increased use of GIS in regional-scale modeling.

Acknowledgements. The authors thank Eugene Pape for field and GIS support, Calvin Meier, Harold Burkhart and Hans Riekerk for use of their research plots. Funding was provided through the USDA Forest Service, Southern Global Change Program.

\section{LITERATURE CITED}

Aber, J. D., Federer, C. A. (1992). A generalized, lumpedparameter model of photosynthesis, evapotranspiration and net primary production in temperate and boreal forest ecosystems. Oecologia 92: 463-474

Combs, S. T., Bowie, L. Y.. Tello, J. C. (1988). Investigation of the response of a large watershed to changes in vegetation: development of the WTRYLD simulation model. In: Proc. Am. Soc. Agric. Eng., Chicago, p. 232-243

Cooter, E. J., Eder, B. K., LeDuc, S. K., Truppi, L. (1993). General circulation model output for forest climate change research and applications. U.S. Dept Agric. For. Serv. gen. tech. Rep. SE-85, Southern Forest Experiment Station, Ashville, NC

Davis, F. W., Quattrochi, D. A., Ridd, M. K., Lam, N., Walsh, S. J., Michaelsen, J. C., Franklin, J., Stow, D. A., Johannsen, C. J., Johnston, C. A. (1991). Environmental analysis using integrated GIS and remotely sensed data: some research needs and priorities. Photogramm. Eng. rem. Sens. 57(6): 689-697

Dawdy, D. R., Lichty, R. W., Bergmann, J. M. (1972). A rainfall-runoff simulation model for estimation of flood peaks for small drainage basins. U.S. Geol. Surv. Prof. Pap. 506-B. Washington, DC
Drayton, R. S., Wilde, B. M., Harris, J. H. K. (1992). Geographical Information System approach to distributed modelling. Hydrol. Process. 6: 361-368

Esser, G. (1992). Implications of climate change for production and decomposition in grasslands and coniferous forests. Ecol. Appl. 2(1): 47-54

Everham, E. M. III, Wooster, K. B., Hall, C. A. S. (1991). Forest regional climate modeling. In: Buford, M. A. (ed.) Proc. Symposium on Systems Analysis in Forest Resources Conference, 1991, Charleston, S. Carolina. General Technical Report SE-74, U.S. Government Printing Office, Washington, DC, p. $11-16$

Federer, C. A., Lash, D. (1978). BROOK: a hydrologic simulation model for eastern forests. Res. Pap. 19, Water Resources Research Center, University of New Hampshire, Durham

Ffolliott, C. A., Guertin, D. P. (1988). YIELD II: an interactive computer model to simulate water yield from southwestern ecosystems. In: Proc. Am. Soc. Agric. Eng., Chicago, p. $72-78$

Iverson, L. R., Risser, P. G. (1987). Analyzing long-term changes in vegetation with Geographic Information System and remotely sensed data. Adv. Space Res. 7(11); 183-194

James, L. D. (1972). Hydrologic modeling, parameter estimation, and watershed characteristics. J. Hydrol. 17: 283-307

Johnson, L. B. (1990). Analyzing spatial and temporal phenomena using geographical information systems. Landscape Ecol. 4(1): 31-43

Johnston, K. M. (1987). Natural resource modeling in the Geographic Information System environment. Photogramm. Eng. rem. Sens. 53(10): 1411-1415

Kelly, J. F. (1991). USDA forest survey methods. In: Jones, R. H. (ed.) Proceedings: Alabama's Forest Resources: Past, Present and Future. Auburn University, Auburn, AL, p. $7-15$

Lanfear, K. J. (1989). Editorial: Geographic Information Systems and water resources applications. Water Resour. Bull. 25(3): v-vi

Long, S. P. (1991). Modification of the response of photosynthetic productivity to rising temperature by atmospheric $\mathrm{CO}_{2}$ concentrations: has its importance been underestimated? Plant Cell Environ. 14: 729-739

Magette, W. L., Shanholtz, V. O., Carr, J. C. (1976). Estimating selected parameters for the Kentucky Watershed Model from watershed characteristics. Water Resour. Res. 12: $472-476$

Marx, D. H. (1988). Southern forest atlas project. In: The 81st annual meeting of The Association Dedicated to Air Pollution Control and Hazardous Waste Management (APCA), Dallas, Texas, 1988. APCA, Pittsburgh. PA, p. 1-24

Mintzer, I. M. (1990). Energy, greenhouse gases, and climate change. A. Rev. Energy 15: 513-550

Moody, D. W., Chase, E. B., Aronson, D. A. (1986). National water summary 1985 hydrologic events and surface-water resources. U.S. Geol. Surv. Water-Supply Pap. 2300, Washington, DC

Mooney, H. A., Vitousek, P. M., Matson, P. A. (1987). Exchange of materials between terrestrial ecosystems and the atmosphere. Science 238: 926-932

Nadelhoffer, K., Aber, J. D., Melillo, J. M. (1985). Fine roots net primary production, and soil nitrogen availability: a new hypothesis. Ecology 66(4): 1377-1390

Nikolov, N. T., Zeller, K. F. (1992). A solar radiation algorithm for ecosystem dynamic models. Ecol Model. 61: 149-168

Osborne, S. (1990). Growth models and geographic information systems. U.S. Dept Agric. For. Serv. gen. tech. Rep. PNW-263, Washington, DC, p. 397-402 
Rastetter, E. B., King, A. W., Cosby, B. J., Hornberger, G. M. O'Neill, R. V., Hobbie, J. E. (1992). Aggregating fine-scale ecological knowledge to model coarser-scale attributes of ecosystems. Ecol. Appl. 2: 55-70

Running, S. W., Coughlan, J. C. (1988). A general model of forest ecosystem processes for regional applications. I Hydrologic balance, canopy gas exchange and primary production processes. Ecol. Model. 42: 125-154

Teskey, R. O., Bongarten, B. C., Cregg, B. M., Dougherty, P. M., Hennessey, T. C. (1987). Physiology and genetics of tree growth response to moisture and temperature stress: an examination of the characteristics of loblolly pine (Pinus taeda L.). Tree Physiol. 3: 41-61

Editor: V. Meentemeyer, Athens, Georgia, USA
Tomlinson, R. F., Calkins, H. W., Marble, D. F. (1976). Computer handling of geographic data. UNESCO Press, Paris

USGS (1992). Regional hydrology and the USGS stream gaging network. National Academy Press, Washington, DC

Verbyla, D. L. (1990). Predicting forest changes associated with climate warming: potential uses of GIS technology. In: Schreier, H. (ed.) Symposium on Management and Productivity of Western-Montane Forest Soils, Boise, ID. Reid, Collins \& Associates, Vancouver, p. 193-195

Wessman, C. A. (1992). Spatial scales and global change: bridging the gap from plots to GCM grid cells. A. Rev. Ecol. Syst. 23: 175-200

Manuscript first received: March 30, 1994

Revised version accepted: July 14, 1994 